\title{
Investigating Heavy Metal Pollution in Mining Brownfield and Its Policy Implications: A Case Study of the Bayan Obo Rare Earth Mine, Inner Mongolia, China
}

\author{
Yuxue Pan $^{1} \cdot$ Haitao $\mathrm{Li}^{1}$
}

Received: 15 April 2015/ Accepted: 6 January 2016/Published online: 20 January 2016

(C) Springer Science+Business Media New York 2016

\begin{abstract}
The rapid urbanization of China and associated demand for land resources necessitates remediation, redevelopment, and reclamation of contaminated soil. Before these measures are taken, a basic investigation and inventory of heavy metal (HM) pollution levels in contaminated soil is necessary for establishing and implementing the redevelopment plan. In the present study, to identify the policy implications of inventorying and mapping HM pollution of soil in brownfields throughout China, the Bayan Obo giant rare earth element (REE)-Nb-Fe ore deposit of Baotou in Inner Mongolia, China, which is the largest REE mineral deposit in the world, was taken as a case study. Soil samples from 24 sites in Bayan Obo mining area (MA) and 76 sites in mine tailing area (TA) were collected for determining contents of soil HMs $(\mathrm{Cr}$, $\mathrm{Cd}, \mathrm{Pb}, \mathrm{Cu}$, and $\mathrm{Zn})$. The results showed that the average concentrations of $\mathrm{Cr}, \mathrm{Cd}, \mathrm{Pb}, \mathrm{Cu}$, and $\mathrm{Zn}$ in both $\mathrm{MA}$ and TA were all higher than their corresponding background values for Inner Mongolia but lower than the Class II criteria of the National Soil Quality Standards of China (GB 15618-1995). Enrichment factor (EF) analysis of the soil samples indicated that the soil in the brownfield sites was highly enriched with $\mathrm{Cr}, \mathrm{Cd}, \mathrm{Pb}, \mathrm{Cu}$, and $\mathrm{Zn}$ compared to the corresponding background values. In MA, the EF for Cd was the highest among the studied elements, while in TA, the EF for $\mathrm{Cr}$ (3.45) was the highest, closely followed by the $\mathrm{EF}$ for $\mathrm{Cd}$ (3.34). The potential ecological risk index
\end{abstract}

Haitao Li

liht@igsnrr.ac.cn

1 Key Laboratory of Land Surface Pattern and Simulation, Institute of Geographical Sciences and Natural Resources Research, Chinese Academy of Sciences, A11 Datun Avenue, Chaoyang District, Beijing 100101, China
(RI) indicated a moderate potential ecological risk from the studied HMs in MA and a low potential ecological risk in TA, and the results of RI also suggested that the soil was most heavily polluted by $\mathrm{Cd}$. According to the spatial distribution maps of $\mathrm{HM}$, contamination hot-spots were primarily located near mining-related high-pollution plants. Based on the results, policy recommendations are proposed related to brownfield management in urban planning.

Keywords Heavy metal pollution - Potential ecological risk - Rare earth mine - Brownfield management

\section{Introduction}

The need for remediation, restoration, and reclamation of contaminated mining soil has grown in recent years and will continue to be a major issue for sustainable regional development (Bradshaw 1997; Chang et al. 2009; Pardo et al. 2014a, b; Wong 2003). This is especially true in China where rapid urbanization is contributing to increasing demand for land resources, resulting in growing concern about the redevelopment of contaminated soil and its implications for local public health (Li 2006; Miao and Marrs 2000).

Over time, mining and related industrial activities contribute to ecosystem degradation, giving rise to large areas of derelict land (Acosta et al. 2011; Facchinelli et al. 2001; Fryer et al. 2006; Liu et al. 2005; Mirzaei et al. 2014). In the vicinity of a MA, activities such as mineral excavation, ore transportation, smelting, and refining discharge large amounts of spoils, effluents, wastewater, and dust containing heavy metals (HMs) into the soil (Liu et al. 2013; Navarro et al. 2008). This is especially true of places where mining has been carried out for long periods of time 
(decades or even centuries) with little or no environmental regulation enforced (Alloway 2013). In general, all stages of mining produce environmental impacts, resulting in the destruction of natural soils and the creation of new soils (FAO 2014). The new soils are mechanically, physically, chemically, and biologically deficient (Vega et al. 2006), characterized by instability and limited cohesion, with low concentrations of nutrients and organic matter and high levels of HMs (He et al. 2005). HMs are among the most widespread contaminants in the environment (Christoforou et al. 2000), and can be transferred to animals and humans through various exposure pathways such as the food chain and direct contact (Alloway 2013). For instance, chronic $\mathrm{Cd}$ exposure might cause diseases such as pulmonary adenocarcinomas, lung cancer, bone fractures, prostatic proliferative lesions, hypertension, and kidney dysfunction. Moreover, excess intake of $\mathrm{Pb}$, which is an unessential element for human body, would cause damage to the skeletal, nervous, circulatory, immune, endocrine, and enzymatic systems (Zhang et al. 2012), and long-term exposure to high doses of $\mathrm{Zn}$ might diminish immune system function, negatively affect cholesterol balance, and even lead to infertility (Plum et al. 2010).

Soil, as an important carrier of HMs in the terrestrial environment (Nriagu and Pacyna 1988), provides a vital index for investigating the potential risk to public health and the ecosystem (Hough et al. 2004). Studies have shown that the level of HM pollutants in the soil of MAs is higher than areas without mining in several countries including Spain (Navarro et al. 2008), Morocco (Khalil et al. 2014), Italy (Wahsha et al. 2012), and China (Liu et al. 2006; Zhuang et al. 2013). This phenomenon has been mainly attributed to mineral excavation, ore transportation, and smelting in MAs (Escarré et al. 2011; Fu and Wei 2012). The HM contamination of soil in MAs has been and will continue to be of great interest for researchers, city administrations and planners around the world (ArenasLago et al. 2014; Bes et al. 2014; Candeias et al. 2014; Ji et al. 2013; Monterroso et al. 2014; Song et al. 2015; Zhuang et al. 2013).

In China, as a principal raw materials supplier, the mining industry has to expand continuously to meet the demands of the ever-increasing economic growth (Li 2006). However, due to a lack of environmental awareness and technological advancement, mining alone had generated a total of approximately 3.0 million ha of derelict land in China, known as "mining brownfields," by the end of the last century (MEPPRC 2006). This wasteland is increasing at a rate of 46,700 ha per year (Zhuang et al. 2009). Pollution related to mining operations and associated mine tailings causes a direct economic loss of over RMB 9 billion yuan and an indirect loss of about RMB 30 billion yuan each year (Liu and Shu 2003). Following a series of soil pollution problems, numerous studies on the HM contamination of soil in MAs have been carried out over the past decade in China (Fu and Wei 2012; Huang et al. 2013; Huang 2014; Li et al. 2014; Zhao et al. 2012). The results of these studies show that HM pollution in soil is present in various MAs.

Under the circumstances, the increasing number of brownfields has become a major soil-related problem, and brownfield redevelopment presents both a challenge and an opportunity for policy-makers and the scientific community (Chrysochoou et al. 2012; Sardinha et al. 2013). As a country rich in mineral resources, according to the China Mining Association (CMA), China has over 9000 large or medium-sized mines and a total of 178 mining cities, including 68 prefecture-level cities with mining brownfields (CMYED 2007). These mining brownfields typically contain high concentrations of HMs such as cadmium, copper, zinc, and lead from mining activities (Zhao et al. 2012; Zhuang et al. 2013). Often, HMs are strongly partitioned onto (or otherwise associated with) the soil and have "aged" in ways that have reinforced immobilization (Jennings et al. 2002). Hence, the problems of HMs and lingering environmental liability are significant challenges for brownfield redevelopment. However, with a relatively short history of industrialization, brownfields, especially mining brownfields, are a new phenomenon which first occurred in the 1990s (Cheng et al. 2011). Brownfield redevelopment studies and practices in China are in the early stages of development (Zhang et al. 2007). Therefore, an investigation of HM pollution in brownfield sites is necessary and useful before a plan for brownfield redevelopment is made.

To make a basic investigation and inventory of the soil quality in terms of HM pollution at the brownfield sites, a case study of the Bayan Obo giant REE-Nb-Fe ore deposit was performed. The objectives of this study are (1) to determine the levels of soil contamination; (2) to investigate the spatial distribution of HMs including $\mathrm{Cr}$, $\mathrm{Cd}, \mathrm{Pb}, \mathrm{Cu}$, and $\mathrm{Zn}$; (3) to discover hot-spots of $\mathrm{HM}$ pollution using geographical information system technology (GIS); (4) to assess the potential ecological risk in the study area. Next, policy recommendations related to brownfield management in urban planning are proposed based on the results.

\section{Materials and Methods}

\section{Study Area and Soil Sampling}

The Bayan Obo giant REE-Nb-Fe ore deposit in Baotou $\left(40^{\circ} 14^{\prime} 56^{\prime \prime}-42^{\circ} 43^{\prime} 49^{\prime \prime} \mathrm{N}, \quad 109^{\circ} 15^{\prime} 12^{\prime \prime}-111^{\circ} 26^{\prime} 25^{\prime \prime} \mathrm{E}\right), \quad$ an integrated industrial city based on metallurgy, rare earth 
production, and machinery manufacturing, is well known as the largest rare earth element (REE) mineral deposit in the world, as well as a major producer of $\mathrm{Nb}$ and $\mathrm{Fe}$ producer (Drew et al. 1990)). The Bayan Obo deposits have three main ore zones: the Main Orebody, the East Orebody, and the West Orebody, lying along an east-west zone more than $18 \mathrm{~km}$ long (Wu 2008). The Main and the East Orebodies, both of which include iron-REE resources with more than $1000 \mathrm{~m}$ of strike length and an average 5.41 and $5.18 \%$ rare earth oxides (REOs), respectively, are much larger than the West Orebody (Yuan et al. 1992). Longterm mining activities in the area have produced a large amount of tailings. The TA covers $11.5 \mathrm{~km}^{2}$, with 150 million tonnes of tailings, of which approximately 9.3 million tonnes are REE tailings ( $\mathrm{Li}$ et al. 2010). Almost $90 \%$ of the mined deposit was stored in the tailing dam of the Baotou Iron and Steel Group Company, which is $12 \mathrm{~km}$ away from Baotou city and was established in 1965 with poor support capacity (Guo et al. 2013). After years of mining and ore processing, large areas of brownfields were created in the vicinity of the MA and the tailing dam. The present study sites are located in the brownfields of the Bayan Obo mine and the tailing dam with a large amount of REEs and HMs.
The location of the sampling points is shown in Figs. 1 and 2. A total of 100 samples, taken from the surface soil of the brownfield at a depth of 0-20 cm, were collected from both the mining area (MA, 24 samples) and the tailing area (TA, 76 samples). To enhance the representativeness of the sample from each sampling site, five sub-samples were obtained from different cells with a $1 \mathrm{~m} \times 1 \mathrm{~m}$ grid to form a composite sample $(1.0 \mathrm{~kg})$, with GPS recording its location. Next, the samples kept in labeled polyethylene bags were transported to the laboratory for further analysis.

\section{Analytic Methods and Quality Control}

All analyses were completed in the laboratory of the Institute of Geographic Sciences and Natural Resources Research, Chinese Academy of Sciences, Beijing, China. First, each sample was air-dried at room temperature to constant weight, sifted through a 2-mm nylon sieve to remove coarse debris, ground gently with an agate pestle and mortar, sifted with a $63-\mu \mathrm{m}$ mesh sieve for homogenization, and stored in self-sealing polyethylene bags. Then the samples were digested with an acid mixture $\left(\mathrm{HNO}_{3}\right.$ :$\mathrm{HClO}_{4}: \mathrm{HF}$ ratio of $3: 1: 1$, which was cooled to room temperature and diluted with deionized water after being

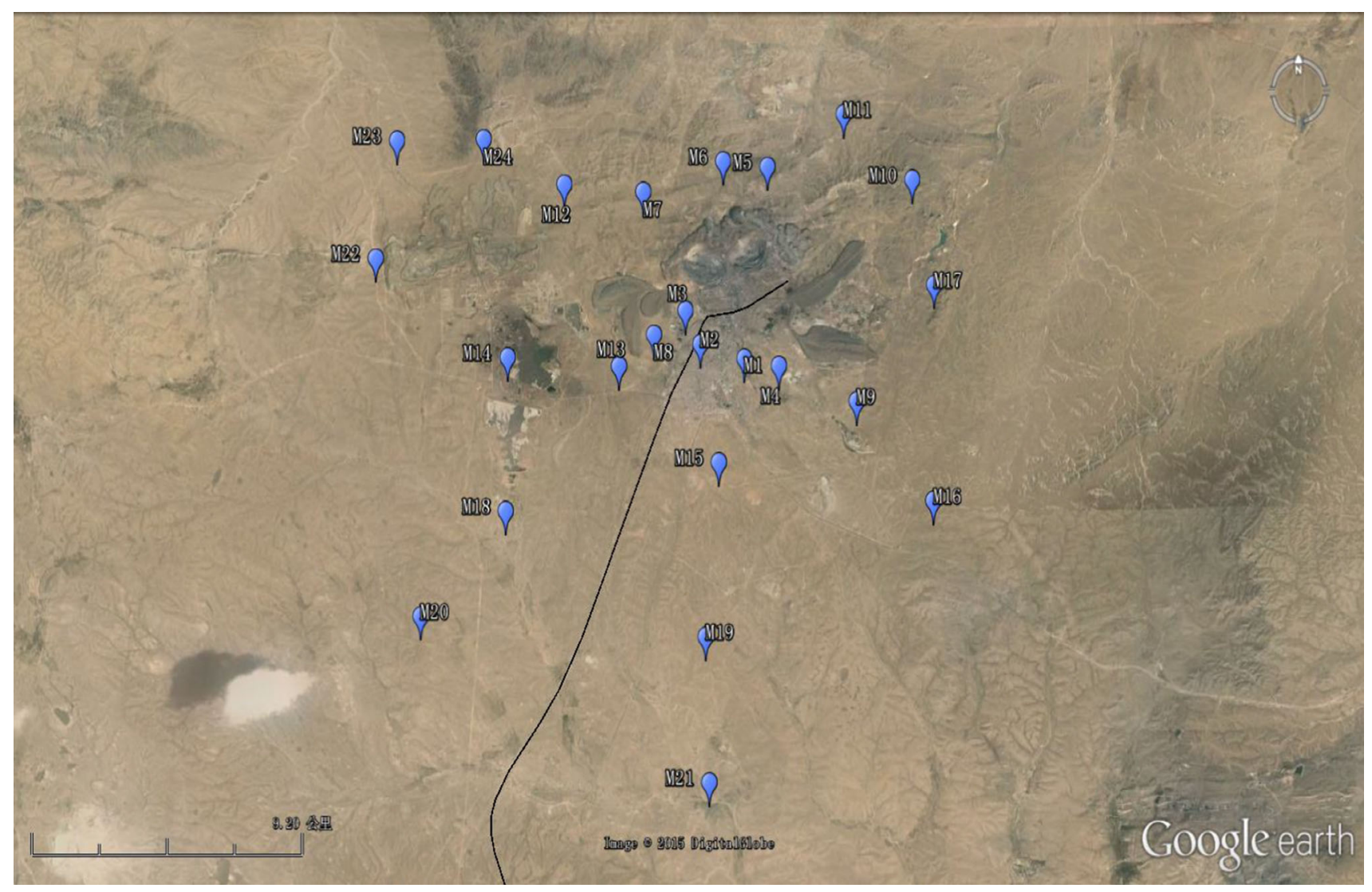

Fig. 1 Spatial distribution of sampling sites in MA. Blue icons denote sampling sites in MA (Color figure online) 


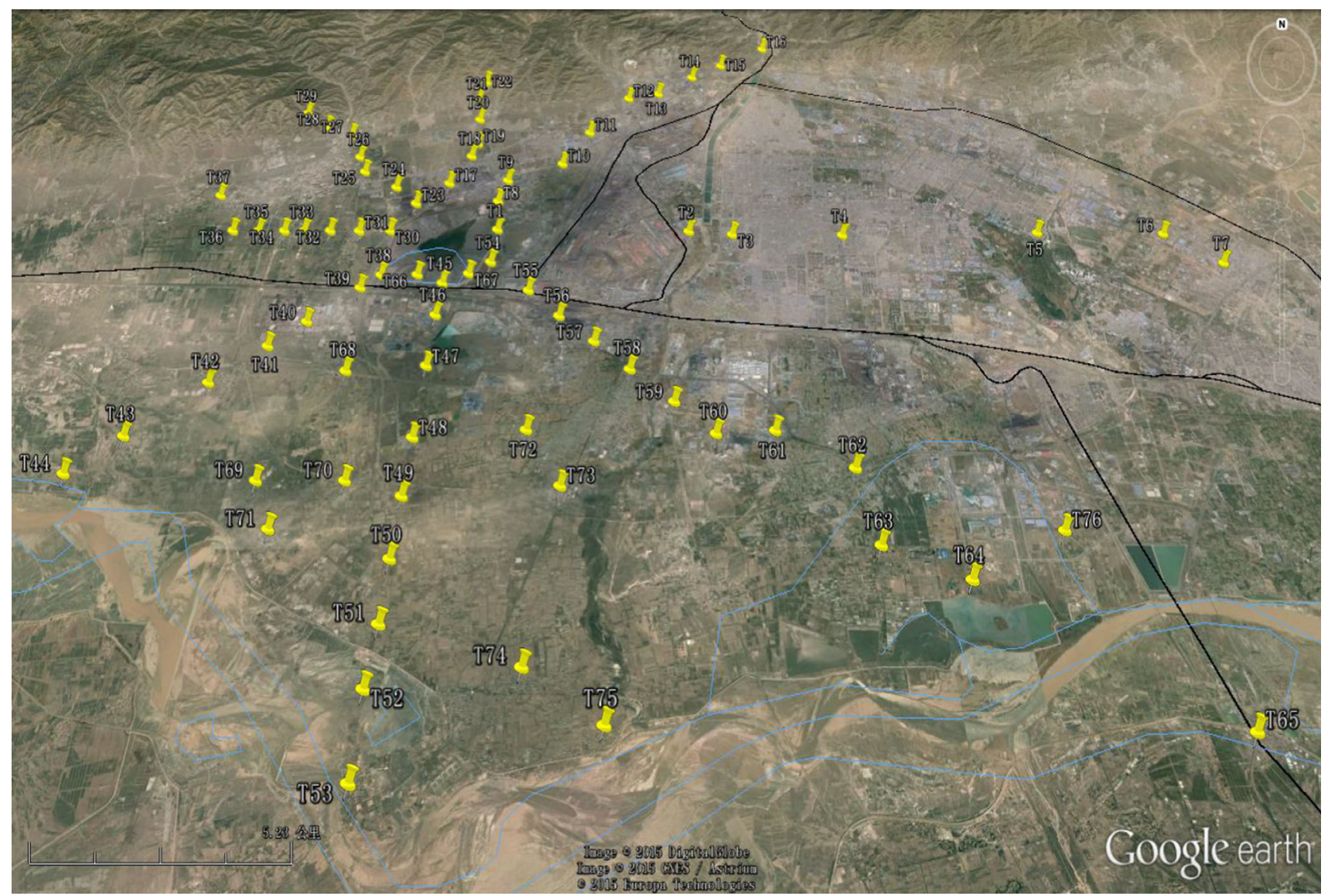

Fig. 2 Spatial distribution of sampling sites in TA. Yellow icons denote sampling sites in TA (Color figure online)

heated at $180{ }^{\circ} \mathrm{C}$ for $10 \mathrm{~h}$. The HM contents were determined according to national standard methodologies (NSPRC 1995).

Concentrations of $\mathrm{Cr}, \mathrm{Pb}, \mathrm{Cu}$, and $\mathrm{Zn}$ were determined using inductively coupled plasma optical emission spectrometry (ICP-OES; PE, USA), while concentrations of Cd were determined using inductively coupled plasma mass spectrometry (ICP-MS; PE, USA). Reagent blanks, sample replicates, and standard reference materials (GBW07429), obtained from the Centre of National Standard Reference Material of China, were analyzed as part of the quality assurance and quality control (QA/QC) procedures. The relative errors of the results were better than $5 \%$ on average.

\section{Statistical Methods and Assessment of Soil Pollution}

Statistical indicators, such as the means, ranges, and standard deviations (SD), were obtained using IBM SPSS Statistics 20.0 software. To measure the HM pollution level, two typical indices were employed: the enrichment factor (EF) and the potential ecological risk index (RI).

The EF was based on the standardization of a tested element against a reference element. The EFs for the soil samples were calculated relative to the background concentrations; thus, the EF equals the element's measured concentration divided by background element concentration. If $\mathrm{EF} \leq 1$, the soils of the study area would not be enriched with HMs, whereas EF $>1$ indicates HM enrichment.

The potential ecological RI was proposed to measure the overall ecological risk of multiple HMs (Hakanson 1980). The potential ecological risk coefficient $\left(E_{\mathrm{r}}^{i}\right)$ is defined as

$E_{\mathrm{r}}^{i}=T_{\mathrm{r}}^{i} \times C_{\mathrm{f}}^{i}=\frac{T_{\mathrm{r}}^{i} \times C_{\mathrm{s}}^{i}}{C_{n}^{i}}$

where $T_{\mathrm{r}}^{i}$ is the toxic-response factor of $\mathrm{HM} i$ [i.e., for $\mathrm{Cd}$, $\mathrm{Cr}, \mathrm{Cu}, \mathrm{Pb}$, and $\mathrm{Zn} 30,2,5,5$, and 1 , respectively (Hakanson 1980)], which reflects the toxicity level and sensitivity of organisms to the metal; $C_{\mathrm{f}}^{i}$ is the contamination factor of $\mathrm{HM} i ; C_{\mathrm{s}}^{i}$ is the measured concentration of HM $i ; C_{n}^{i}$ is the background value of HMs $i$. $E_{\mathrm{r}}^{i}$ gives an indication of ecological risk: $E_{\mathrm{r}}^{i}<40$, low risk; $40<E_{\mathrm{r}}^{i}<80$, moderate risk; $80<E_{\mathrm{r}}^{i}<160$, considerable risk; $160<E_{\mathrm{r}}^{i}<320$, very high risk; $E_{\mathrm{r}}^{i}>320$, dangerous.

The potential ecological RI was calculated using the following formula: 
$\mathrm{RI}=\sum_{i=1}^{n} E_{\mathrm{r}}^{i}$

where $n$ is the number of HMs analyzed in the sample (i.e., $n=5$ in the present study). RI can be classified into four levels: $\mathrm{RI}<150$ : low risk, $150 \leq \mathrm{RI}<300$ : moderate risk, $300 \leq \mathrm{RI}<600$ : considerable risk, and $\mathrm{RI} \geq 600$ : very high risk (Hakanson 1980).

\section{Spatial Analysis}

The HM concentrations were then input to a grid-based contouring map to study the distribution of HMs in the soil. The inverse distance weighted (IDW) interpolation method was adopted for the interpolation of geographical data. Inverse distance weighting (IDW) is an interpolation method applied widely to study the spatial variation and distribution of numerous parameters including metallic elements (Lam 2009; Xie et al. 2011). IDW estimates values with a linear combination of values at sampled points weighted by an inverse function of the distance from the point of interest to the sampled points. This assumes that the values of points not sampled that are closer to the sampled point are more similar to the sampled point than those further away (Li and Heap 2011). The interpolating function is

$Z(x)=\sum_{i=1}^{n} w_{i} z_{i} / \sum_{i=1}^{n} w_{i}$

$w_{i}=d_{i}^{-\mathrm{u}}$

where $Z(x)$ is the predicted value at an interpolated point, $z_{i}$ is the value at a known point, $n$ is the total number of known points used in interpolation, $d_{i}$ is the distance between point $i$ and the prediction point, and $w_{i}$ is the weight assigned to point $i$. Greater weighting values are assigned to values closer to the interpolated point. As the distance increases the weight decreases (Shepard 1968) and $\mathrm{u}$ is the weighting power that decides how the weight decreases as the distance increases.

IDW was performed in the software program ArcGIS 9.30 (Environmental Systems Research Institute Inc., Redlands, CA, USA).

\section{Results and Discussion}

\section{Concentrations of Heavy Metals}

The descriptive statistics of target HM concentrations in the soils of MA and TA are shown in Tables 1 and 2. These results demonstrated a general enrichment of HMs in the soil with respect to background values (Xu and Tao 2004).
The results showed that the average concentrations of $\mathrm{Cr}$, $\mathrm{Cd}, \mathrm{Pb}, \mathrm{Cu}$, and $\mathrm{Zn}$ in both MA and TA were all higher than their corresponding background values for Inner Mongolia but lower than the Class II criteria of the National Soil Quality Standards of China (GB 156181995). In the soil of MA, the average concentrations of $\mathrm{Cu}$, $\mathrm{Zn}, \mathrm{Pb}, \mathrm{Cd}$, and $\mathrm{Cr}$ in the collected samples were approximately $2.4,2.2,3.7,5.2$, and 3.6 times as high as their background levels, respectively. In the soil of TA, the average concentrations of $\mathrm{Cu}, \mathrm{Zn}, \mathrm{Pb}, \mathrm{Cd}$, and $\mathrm{Cr}$ in the collected samples were approximately $2.2,1.8,2.5,3.3$, and 3.5 times as high as their background levels, respectively. Therefore, the results suggested that the enrichment of $\mathrm{Cu}, \mathrm{Zn}, \mathrm{Pb}, \mathrm{Cd}$, and $\mathrm{Cr}$ existed for most of the plots sampled in MA and TA. High concentrations coupled with high SD values suggested anthropogenic sources for each of these elements (Manta et al. 2002). Meanwhile, as shown in Tables 1 and 2, the highest variability among all metals in the soil occurred with $\mathrm{Pb}$ concentration, ranging widely with a high coefficient of variation, reflecting the heterogeneity in its distribution in the environment, as well as the possible existence of point sources contributing large amounts of $\mathrm{Pb}$ in some of the samples. Almost all of the HMs studied showed high concentrations (above background values) coupled with high coefficients of variation, which indicated the soils were polluted by HMs in the brownfields (Esmaeili et al. 2014).

A comparison of soil HM concentrations in our studied areas with those in other regions is shown in Table 3. Compared to China' other MAs, smelting sites and the e-waste dismantling area, the HM concentrations in soil of our study areas were much lower ( $\mathrm{Li}$ et al. 2011, 2014, 2015; Wei et al. 2009; Yan et al. 2015). However, the HM concentrations in soil of our study areas were comparable to those of a plastic waste recycling area with moderate to high metal pollution(Tang et al. 2015), and obviously higher than those observed from the contaminated urban areas in China (Cheng et al. 2014). Thus, the studied areas were suffering from moderate to high HM pollution.

\section{Assessment of Heavy Metal Pollution and Environmental Risk}

The EFs for soil samples were analyzed in terms of the background concentrations of Inner Mongolia, and the results are shown in Tables 4 and 5. Compared with the background values, the soil in the brownfield sample sites was generally enriched in $\mathrm{Cu}, \mathrm{Zn}, \mathrm{Pb}, \mathrm{Cd}$, and $\mathrm{Cr}$. In MA, the $\mathrm{EF}$ for $\mathrm{Cd}$ was the highest among the studied elements, indicating extremely high Cd pollution of the MA brownfield sites (Table 4). In TA, the EF for $\mathrm{Cr}$ (3.45) was the highest among the studied elements, closely followed by the $\mathrm{EF}$ for $\mathrm{Cd}$ (3.34), indicating high $\mathrm{Cd}$ and $\mathrm{Cr}$ pollution of 
Table 1 Statistics heavy metal concentration at the mining sites $(\mathrm{mg} / \mathrm{kg})$
Table 2 Statistics of heavy metal concentration at the tailing dam sites $(\mathrm{mg} / \mathrm{kg})$

\begin{tabular}{lcrrrr}
\hline & $\mathrm{Cu}$ & $\mathrm{Zn}$ & $\mathrm{Pb}$ & $\mathrm{Cd}$ & $\mathrm{Cr}$ \\
\hline Maximum & 60.50 & 592.80 & 395.60 & 0.426 & 175.80 \\
Minimum & 18.35 & 33.55 & 17.92 & 0.0002 & 61.09 \\
Mean & 30.40 & 103.94 & 49.49 & 0.193 & 128.76 \\
Median & 23.83 & 72.20 & 25.99 & 0.252 & 131.75 \\
Standard deviation & 12.73 & 112.98 & 76.63 & 0.140 & 27.15 \\
Coefficient of variation (\%) & 41.89 & 108.70 & 154.83 & 72.561 & 21.09 \\
Background values of Inner Mongolia $^{\mathrm{a}}$ & 12.74 & 47.54 & 13.52 & 0.037 & 35.73 \\
National soil quality standards (Class II) & 100 & 250 & 300 & 0.3 & 200 \\
\hline
\end{tabular}

${ }^{\mathrm{a}} \mathrm{Xu}$ and Tao (2004)

\begin{tabular}{|c|c|c|c|c|c|}
\hline & $\mathrm{Cu}$ & $\mathrm{Zn}$ & $\mathrm{Pb}$ & $\mathrm{Cd}$ & $\mathrm{Cr}$ \\
\hline Maximum & 119.90 & 390.20 & 433.00 & 0.375 & 302.50 \\
\hline Minimum & 8.03 & 24.87 & 12.07 & 0.000 & 60.90 \\
\hline Mean & 27.53 & 83.59 & 33.73 & 0.122 & 124.09 \\
\hline Median & 19.14 & 62.60 & 21.47 & 0.125 & 120.85 \\
\hline Standard deviation & 20.95 & 59.42 & 51.48 & 0.088 & 40.99 \\
\hline Coefficient of variation (\%) & 76.11 & 71.09 & 152.64 & 72.349 & 33.03 \\
\hline Background value of Inner Mongolia $^{a}$ & 12.74 & 47.54 & 13.52 & 0.037 & 35.73 \\
\hline National soil quality standards (Class II) & 100 & 250 & 300 & 0.3 & 200 \\
\hline
\end{tabular}

${ }^{\mathrm{a}} \mathrm{Xu}$ and Tao (2004)

Table 3 Comparison of mean HM concentrations $(\mathrm{mg} / \mathrm{kg}$ ) in soil samples from different areas

\begin{tabular}{llllllll}
\hline Location & Sampling surroundings & $\mathrm{Cd}$ & $\mathrm{Cr}$ & $\mathrm{Cu}$ & $\mathrm{Pb}$ & $\mathrm{Zn}$ & $\mathrm{Reference}$ \\
\hline Baotou, China & REE-Nb-Fe mining area & 0.193 & 128.8 & 30.4 & 49.5 & 103.9 & This study \\
& Tailing dam & 0.122 & 124.1 & 27.5 & 33.7 & 27.5 & This study \\
Wen'an, China & Plastic waste recycling area & 0.381 & 92.2 & 41.8 & 57.2 & 124 & Tang et al. (2015) \\
Hunan, China & Shuikoushan mining-smelting area & 10.34 & 46.6 & 92.7 & 629 & 597 & Wei et al. (2009) \\
Quzhou, China & A lead-zinc mine & 1.04 & 58.87 & 42.53 & 542.0 & 405.3 & Yan et al. (2015) \\
Guiyu, China & An e-waste dismantling area & 1.21 & 2600 & 4800 & 150 & 330 & Li et al. (2011) \\
Yunnan, China & A 60-year-old Pb/Zn smelter & 12.8 & 104 & 239 & 712 & 1688 & Li et al. (2015) \\
31 metropolises in China & Contaminated urban areas & 0.141 & 73 & 26.9 & 26.0 & 72 & Cheng et al. (2014) \\
22 provinces in China & 72 mining areas & 11.0 & 84.3 & 212 & 641 & 1163 & Li et al. (2014) \\
\hline
\end{tabular}

the TA brownfield sites. This suggested that $\mathrm{Cd}$ and $\mathrm{Cr}$ remediation should be the main objective of the local government risk management activities.

In addition, high $\mathrm{EFs}$ for $\mathrm{Cu}, \mathrm{Zn}, \mathrm{Pb}, \mathrm{Cd}$, and $\mathrm{Cr}$ obtained in a number of soil samples indicated considerable mixed HM pollution. Similarly, the soil in MA showed a similar degree of pollution for $\mathrm{Zn}, \mathrm{Pb}$, and $\mathrm{Cd}$, the EFs of which were all over 1.0. In the case of $\mathrm{Cu}$ and $\mathrm{Cr}$, although the EFs of a few samples were less than 1.0, the average EFs were still over 2.0, indicating the existent of enrichment in the soil of MA.
Table 4 Enrichment factors (EFs) for heavy metals in MA

\begin{tabular}{llllll}
\hline Elements & $\mathrm{Cu}$ & $\mathrm{Zn}$ & $\mathrm{Pb}$ & $\mathrm{Cd}$ & $\mathrm{Cr}$ \\
\hline Maximum & 4.75 & 4.59 & 7.81 & 11.53 & 4.92 \\
Minimum & 1.44 & 0.71 & 1.33 & 0.01 & 1.71 \\
Median & 1.87 & 1.35 & 1.92 & 6.82 & 3.69 \\
Mean & 2.39 & 1.72 & 2.56 & 5.21 & 3.60 \\
Standard deviation & 1.00 & 0.93 & 1.55 & 3.78 & 0.76 \\
Percent of EF $>1(\%)$ & 71 & 100 & 100 & 100 & 79 \\
\hline
\end{tabular}


Table 5 Enrichment factors (EFs) for heavy metals in TA

\begin{tabular}{llllll}
\hline Elements & $\mathrm{Cu}$ & $\mathrm{Zn}$ & $\mathrm{Pb}$ & $\mathrm{Cd}$ & $\mathrm{Cr}$ \\
\hline Maximum & 9.41 & 5.55 & 11.80 & 10.13 & 8.47 \\
Minimum & 0.63 & 0.52 & 0.89 & 1.70 & 1.70 \\
Median & 1.50 & 1.31 & 1.58 & 3.37 & 3.37 \\
Mean & 2.16 & 1.67 & 2.10 & 3.34 & 3.45 \\
Standard deviation & 1.66 & 1.01 & 1.66 & 2.37 & 1.14 \\
Percent of EF $>1(\%)$ & 79 & 100 & 87 & 95 & 71 \\
\hline
\end{tabular}

In the soil of TA, the number of EFs over 1.0 for the elements considered was ranked in the following order: $\mathrm{Zn}>\mathrm{Cd}>\mathrm{Pb}>\mathrm{Cu}>\mathrm{Cr}$. All the EFs for $\mathrm{Zn}$ were over 1.0 , but its average $\mathrm{EF}$ was the lowest, indicating slight $\mathrm{Zn}$ pollution throughout the study area. High average EF coupled with a large percentage of EFs over 1.0 for $\mathrm{Cd}$ suggested extremely high Cd pollution in TA. While the percent of EFs over 1.0 for $\mathrm{Cr}$ was the lowest, its average EF was the highest, indicating the existence of hot-spots for Cr pollution. The identification of hot-spots will be discussed in the next section.

Over all, the EF analysis showed the study area was strongly affected by mining activities (such as ore excavating, smelting, and refining), and some activities left residues of more than one HM pollutant.

To further investigate the degree of soil HM contamination and ecological hazard in MA and TA, the potential ecological risk coefficient $E_{\mathrm{r}}^{i}$ and the potential ecological RI (Tables 6,7) were analyzed. The potential ecological RI integrates the concentration of HMs with ecological effect, environmental effect and toxicology and is used to assess HM pollution and ecological hazard (Hakanson 1980). Based on the Hakanson's approach, the toxic-response factors for $\mathrm{Cr}, \mathrm{Pb}, \mathrm{Cu}, \mathrm{Cd}$, and $\mathrm{Zn}$ are 2, 5, 5, 30, and 1, respectively.

In MA, the results showed the $E_{\mathrm{r}}^{i}$ of HMs were ranked in the following order: $\mathrm{Zn}<\mathrm{Cr}<\mathrm{Cu}<\mathrm{Pb}<\mathrm{Cd}$. The mean values of $E_{\mathrm{r}}^{\mathrm{i}}$ for most $\mathrm{HMs}$, including $\mathrm{Cr}, \mathrm{Pb}, \mathrm{Cu}$, and $\mathrm{Zn}$, were no more than 40 , suggesting a low ecological risk in the soil. In contrast, $\mathrm{Cd}$ had a higher $E_{\mathrm{r}}^{i}$ mean value (156.24), indicating a considerable ecological risk. According to Table 8, the $E_{\mathrm{r}}^{\mathrm{i}} \mathrm{s}$ of $\mathrm{Cr}, \mathrm{Cu}$, and $\mathrm{Zn}$ were no more than 40 in all samples. Only one soil sample had an $E_{\mathrm{r}}^{i}$ value for lead $\mathrm{Pb}$ that was higher than 80 . The $E_{\mathrm{r}}^{i}$ values of the other pollutants were far lower, indicating low ecological risk for $\mathrm{Cr}, \mathrm{Cu}, \mathrm{Pb}$, and $\mathrm{Zn}$ in MA. For $\mathrm{Cd}$, approximately $67 \%$ of the $E_{\mathrm{r}}^{\mathrm{i}}$ values were higher than 160 , with a maximum of 345.8, indicating high ecological risk for $\mathrm{Cd}$ in the soil of MA. It was concerning that the average ecological risk of $\mathrm{Cd}$ in the studied area was significantly

Table 8 Frequencies of potential ecological risk coefficient and potential ecological risk index in MA $(\%)$

\begin{tabular}{lllllll}
\hline Level of risk & $\mathrm{Cr}$ & $\mathrm{Cu}$ & $\mathrm{Pb}$ & $\mathrm{Zn}$ & $\mathrm{Cd}$ & $\mathrm{RI}$ \\
\hline Low risk & 100 & 100 & 96 & 100 & 29 & 29 \\
Moderate risk & 0 & 0 & 0 & 0 & 4 & 63 \\
Considerable risk & 0 & 0 & 4 & 0 & 0 & 8 \\
Very high risk & 0 & 0 & 0 & 0 & 63 & 0 \\
Dangerous risk & 0 & 0 & 0 & 0 & 4 & 0 \\
\hline
\end{tabular}

Table 6 Potential risk index for soil heavy metals in the mining area (MA)

\begin{tabular}{llllllll}
\hline & $\mathrm{Cr}$ & $\mathrm{Cu}$ & $\mathrm{Pb}$ & $\mathrm{Zn}$ & $\mathrm{Cd}$ & $\mathrm{RI}$ & Level of risk \\
\hline Maximum & 9.84 & 23.74 & 146.30 & 12.47 & 345.75 & 401.63 & Considerable risk \\
Minimum & 3.42 & 7.20 & 6.63 & 0.71 & 0.19 & 33.02 & Low risk \\
Mean & $7.21 \pm 0.31$ & $11.93 \pm 1.02$ & $18.30 \pm 5.78$ & $2.19 \pm 0.49$ & $156.24 \pm 23.14$ & $195.87 \pm 21.99$ & Moderate risk \\
Geometric mean & 7.02 & 11.12 & 12.57 & 1.68 & 31.31 & 152.43 & Moderate risk \\
Median & 7.38 & 9.35 & 9.61 & 1.52 & 204.73 & 230.00 & Moderate risk \\
Standard deviation & 1.52 & 5.00 & 28.34 & 2.38 & 113.37 & 107.71 & - \\
\hline
\end{tabular}

Table 7 Potential risk index for soil heavy metals in the tailing dam area (TA)

\begin{tabular}{llllllll}
\hline & $\mathrm{Cr}$ & $\mathrm{Cu}$ & $\mathrm{Pb}$ & $\mathrm{Zn}$ & $\mathrm{Cd}$ & $\mathrm{RI}$ & Level of risk \\
\hline Maximum & 16.93 & 47.06 & 160.13 & 8.21 & 303.95 & 355.69 & Considerable risk \\
Minimum & 3.41 & 3.15 & 4.46 & 1.415 & 0.10 & 28.41 & Low risk \\
Mean & $6.95 \pm 0.26$ & $10.80 \pm 0.94$ & $12.47 \pm 2.18$ & $1.76 \pm 0.14$ & $98.91 \pm 8.21$ & $130.89 \pm 7.92$ & Low risk \\
Geometric mean & 6.60 & 8.87 & 9.22 & 1.47 & 27.41 & 111.46 & Low risk \\
Median & 6.76 & 7.51 & 7.94 & 1.32 & 101.63 & 123.50 & Low risk \\
Standard deviation & 2.29 & 8.22 & 19.04 & 1.25 & 71.56 & 69.01 & - \\
\hline
\end{tabular}


larger than that of the other four HMs. Generally, nonferrous metal mining and refining, manufacturing and application of phosphate fertilizers, and waste disposal are the main anthropogenic sources of cadmium in the environment (ATSDR 2008). This once again suggested that Cd remediation should be the main objective of local government risk management activities in MA.

The potential ecological risk indices (RI) for most sampling sites $(71 \%)$ were more than 150 , indicating at least moderate ecological risk from the studied HMs in MA. Two of the sampling sites near the Main orebody were more seriously polluted than the other sampling sites, with RI values larger than 300 , indicating considerable risk from HM pollution caused by mining activities.

In TA, as shown in Tables 7 and 9, the sequence of the average $E_{\mathrm{r}}^{i}$ for $\mathrm{HMs}$ was $\mathrm{Cd}>\mathrm{Pb}>\mathrm{Cu}>\mathrm{Cr}>\mathrm{Zn}$, consistent with that in MA. Moreover, except for $E_{\mathrm{r}}^{i}$ of $\mathrm{Cd}$ (98.91), which suggested a considerable potential ecological risk, the other HMs posed low ecological risk with $E_{\mathrm{r}}^{i}<40$. The $E_{\mathrm{r}}^{i} \mathrm{~s}$ of $\mathrm{Cr}$ and $\mathrm{Zn}$ in all samples were no more than 40 . For $\mathrm{Cu}$ and $\mathrm{Pb}$, only one and two soil samples, respectively, had $E_{\mathrm{r}}^{i}$ values higher than 40 , and the values for the other samples were far less, indicating low ecological risk for $\mathrm{Cr}, \mathrm{Cu}, \mathrm{Pb}$, and $\mathrm{Zn}$ in $\mathrm{TA}$. For $\mathrm{Cd}$, approximately 9 and $53 \%$ of the sampling sites exhibited moderate and considerable risk, respectively $\left(40<E_{\mathrm{r}}^{i}<80,80<E_{\mathrm{r}}^{i}<160\right)$, and $15 \%$ of the sampling sites exhibited very high risk $\left(160<E_{\mathrm{r}}^{i}<320\right)$. These sites with extremely high $E_{\mathrm{r}}^{i}$ values, coincided with the locations of smelting factories. It therefore appeared that mining industrial activities severely affected the soil environmental quality of the brownfield sites in TA.

On the whole, the calculated RI values ranged from 28.41 to 355.69 with an average of 130.89 , indicating a low potential ecological risk. Approximately $66 \%$ of the sampling sites had low potential ecological risk, with $31 \%$ showing moderate ecological risk, and $3 \%$ showing considerable potential ecological risk. Those exhibiting considerable potential ecological risk were located at the tailing dam, indicating severe effects of the TA activities on soil environmental quality.

Table 9 Frequencies of potential ecological risk coefficient and potential ecological risk index in TA $(\%)$

\begin{tabular}{lllllll}
\hline Level of risk & $\mathrm{Cr}$ & $\mathrm{Cu}$ & $\mathrm{Pb}$ & $\mathrm{Zn}$ & $\mathrm{Cd}$ & $\mathrm{RI}$ \\
\hline Low risk & 100 & 96 & 92 & 100 & 23 & 66 \\
Moderate risk & 0 & 4 & 4 & 0 & 9 & 31 \\
Considerable risk & 0 & 0 & 4 & 0 & 53 & 3 \\
Very high risk & 0 & 0 & 0 & 0 & 15 & 0 \\
Dangerous risk & 0 & 0 & 0 & 0 & 0 & 0 \\
\hline
\end{tabular}

The contribution of different HMs to potential ecological risk in MA and TA is shown in Fig. 3. According to Fig. 3, Cd was the largest contributor to potential ecological risk in both areas, with a percentage of 80 and $76 \%$, respectively. Each of the other four HMs, with a percentage of no more than $10 \%$, contributed far less to overall risk. This result was highly associated with the toxic-response factor of each of the five $\mathrm{HMs}(\mathrm{Cd}, \mathrm{Cr}, \mathrm{Cu}, \mathrm{Pb}$, and $\mathrm{Zn}$ : 30, $2,5,5$, and 1 , respectively). Yet, the $E_{\mathrm{r}}^{i}$ of $\mathrm{Cd}$ was also much higher than that of the other HMs. Therefore, before the redevelopment of the brownfields, $\mathrm{Cd}$ remediation should be the main objective of local government management activities.

The above assessment indicated the brownfield sites were heavily polluted with $\mathrm{Cr}, \mathrm{Pb}, \mathrm{Cu}$, and $\mathrm{Cd}$. This was especially true of the sites related to ore excavation, smelting, and refining. The differences in soil HM pollution levels among the sampling sites were related to the types and duration of mining industrial activities. The potential ecological risk caused by $\mathrm{Cd}$ was extremely high, resulting in a significant potential risk to environmental quality, the ecosystem, and human health. The enrichment of the other four HMs in soil also caused a relatively low potential ecological risk. Therefore, measures should be taken to reduce soil HM contamination to minimize the risk of adverse environmental and health effects. It is noteworthy, however, that the most concentrated single contaminant may not translate simply into the most important area for remediation or policy intervention from a human or environmental health perspective.

\section{Spatial Distribution of Heavy Metals}

The spatial distribution of HMs in soil was analyzed using ArcGIS. The concentrations were interpolated with the IDW method. The heterogeneous distribution of the HMs at this site is shown in Figs. 4 and 5. Similar spatial distribution patterns of $\mathrm{Cu}, \mathrm{Pb}$, and $\mathrm{Zn}$ were found in the geochemical maps. Their high-value areas mainly concentrated in the northeast and central zone, presenting a trend of high concentration in the northeast and low in the southwest. The concentration of $\mathrm{Cd}$ was low in the central and northwest zone, whereas $\mathrm{Cr}$ was high in the north but low in the south. In addition, the area with high $\mathrm{Cr}$ concentration (higher than the background value) took up $99.9 \%$ of the studied area, while $\mathrm{Cd}, \mathrm{Pb}, \mathrm{Cu}$, and $\mathrm{Zn}$ took up 66.3, 31.1, 16.0, and $18.4 \%$, respectively. All of the studied HMs characterized by higher concentrations were found in the northeast of MA, where the East Orebody of Bayan Obo is located. The Main and the East Orebodies were active for a long time with high mining intensity. Lower concentrations were found in the relatively distant areas with fewer mining 


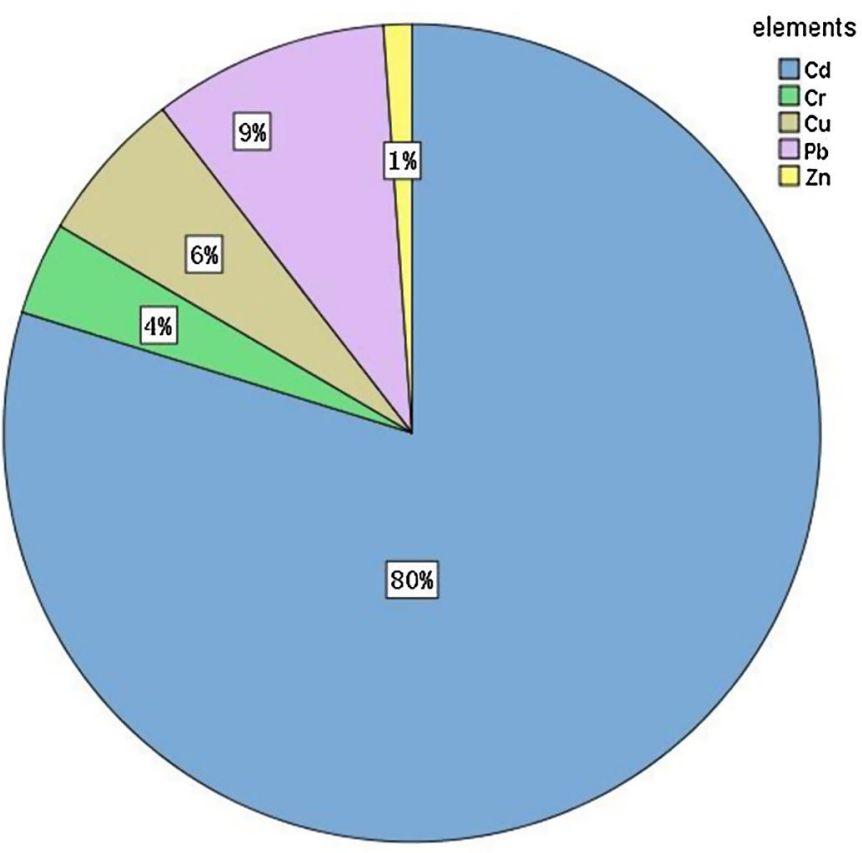

MA

Fig. 3 Contribution of different heavy metals to potential ecological risk in MA and TA. In this figure, the left pie chart illustrates the potential ecological risk contribution of HMs in MA, and the right chart illustrates the potential ecological risk contribution of HMs in

activities. Therefore, it could be concluded that mining activities contributed the increasing concentrations of $\mathrm{HM}$ in the soil (Ji et al. 2013; Liu et al. 2013).

In $\mathrm{TA}$, no similar spatial distribution pattern was found among the five $\mathrm{HMs}$ we investigated. High $\mathrm{Cd}$ concentrations were found in the center and west, while high $\mathrm{Cr}$ concentrations were found in the northwest. Meanwhile, there was a large high concentration or "hot spot" of $\mathrm{Pb}$ in the central zone, with $\mathrm{Cu}$ and $\mathrm{Zn}$ concentrated in the west and central zones. In addition, the concentration of $\mathrm{Cr}$ was higher than the background value in $97.8 \%$ of the study area, and the concentration of the other four HMs was higher than background value in less than 6.0 percent of the area. The high-value areas were distributed mainly in the vicinity of the tailing dam, Baotou Xinheng Coalification Company, Baotou Huadian Branch Company, and Baotou Quanshan Gold Ore Company. It was evident that the distribution of hotspots was consistent with the geographical distribution and spatial scales of the local refineries, suggesting that the accumulation of HMs in the soil was most likely to originate from the tailing dam and industrial processing activities. Previous studies of HM contamination in soil (Esmaeili et al. 2014; Li and Feng 2012; Yang et al. 2011) had shown similar results.

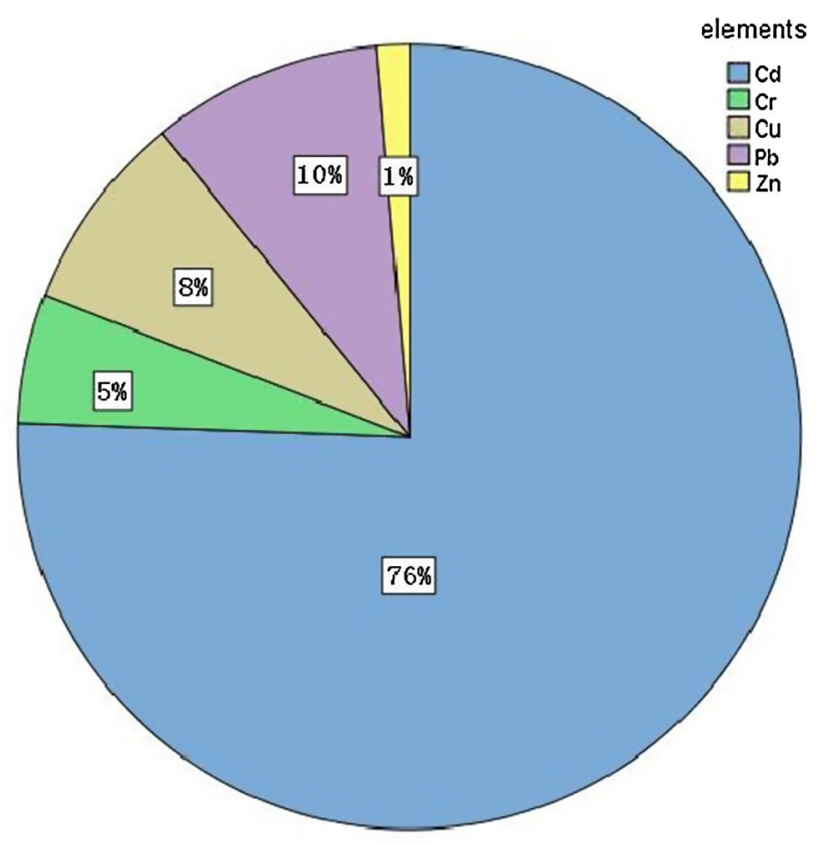

TA

TA. In both charts, the blue area indicates the potential ecological risk contribution of $\mathrm{Cd}$, the green area indicates that of $\mathrm{Cr}$, the brown area indicates that of $\mathrm{Cu}$, the purple area indicates that of $\mathrm{Pb}$ and the yellow area indicates that of $\mathrm{Zn}$ (Color figure online)

The spatial distribution analysis identified several high HM concentration hot-spots in MA and TA. For example, in MA, the $\mathrm{Cr}$ concentration in the sample from Sanli Smelting Plant and the $\mathrm{Pb}$ and $\mathrm{Cd}$ concentrations in samples from Mengyuan Dressing Plant were extremely high compared to the corresponding background values. In TA, the tailing dam and several factories, such as the smelting and refining plants, were co-located with a hot-spot. HM pollution at these sites was found to be more serious and the RI values there were also much higher. Thus miningrelated activities were most likely to be the main source of the HM pollution in the studied area.

Because the redevelopment of brownfield sites in Bayan Obo was included in the Baotou urban plan, some sites which were claimed to have been cleaned up are being redeveloped into commercial and recreational areas. For instance, the brownfield site of Damaoqi Rare-earth Company, which was shut down by the Baotou government because of outdated technology and heavy pollution in 2011, is now redeveloping into a park. It is claimed that the site was cleaned up using physical separation remediation so that the HM concentrations in soil complied with the National Environmental Quality Standards for Soil in China. However, the results of this research indicated that this site remained heavily polluted by HMs 


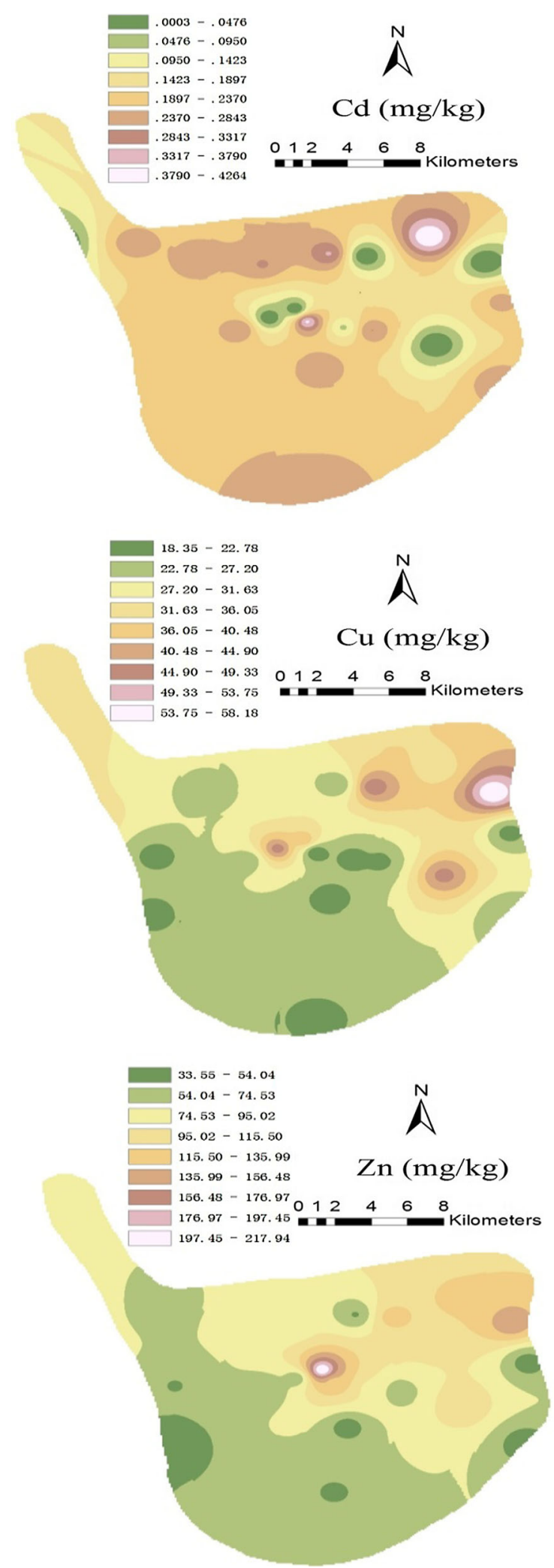

Fig. 4 Spatial distribution of $\mathrm{Cd}, \mathrm{Cr}, \mathrm{Cu}, \mathrm{Pb}$, and $\mathrm{Zn}$ in MA. In this figure, as the legend shows, color is used to indicate heavy metal concentrations. From dark green to white, the values change from the
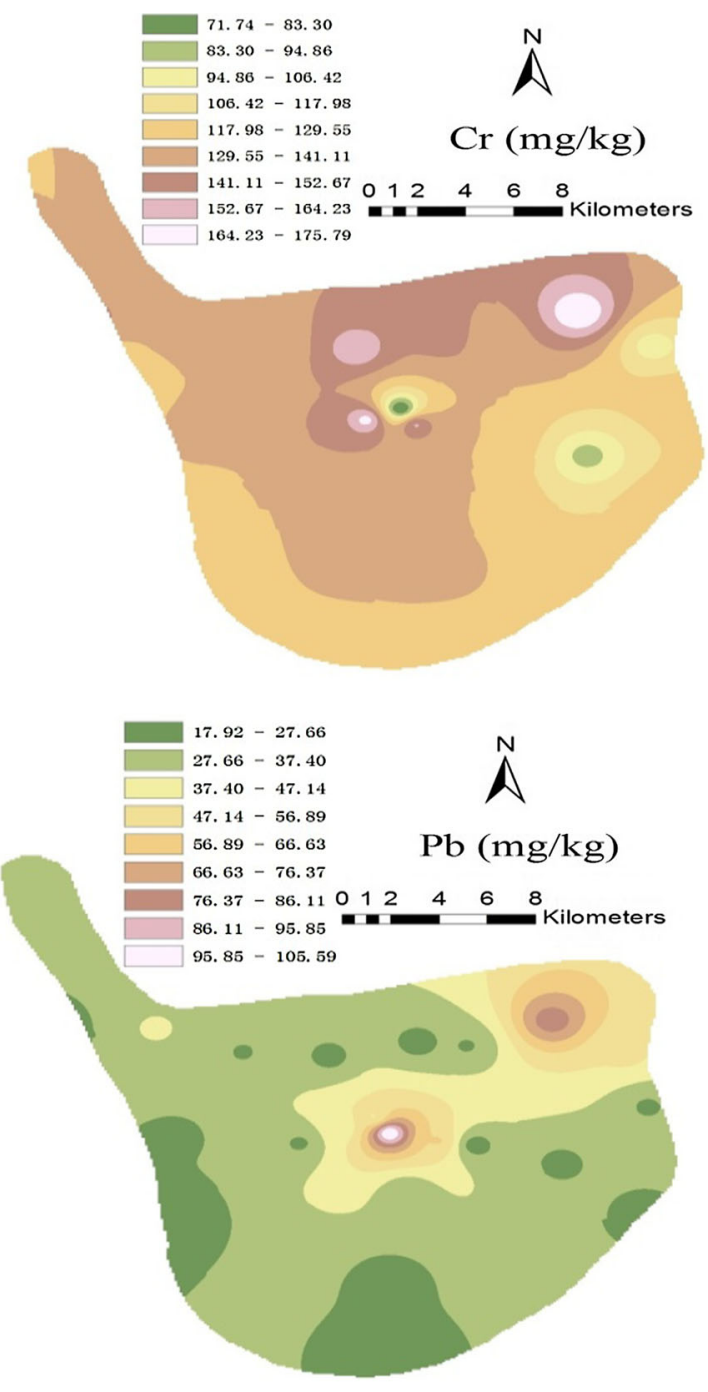

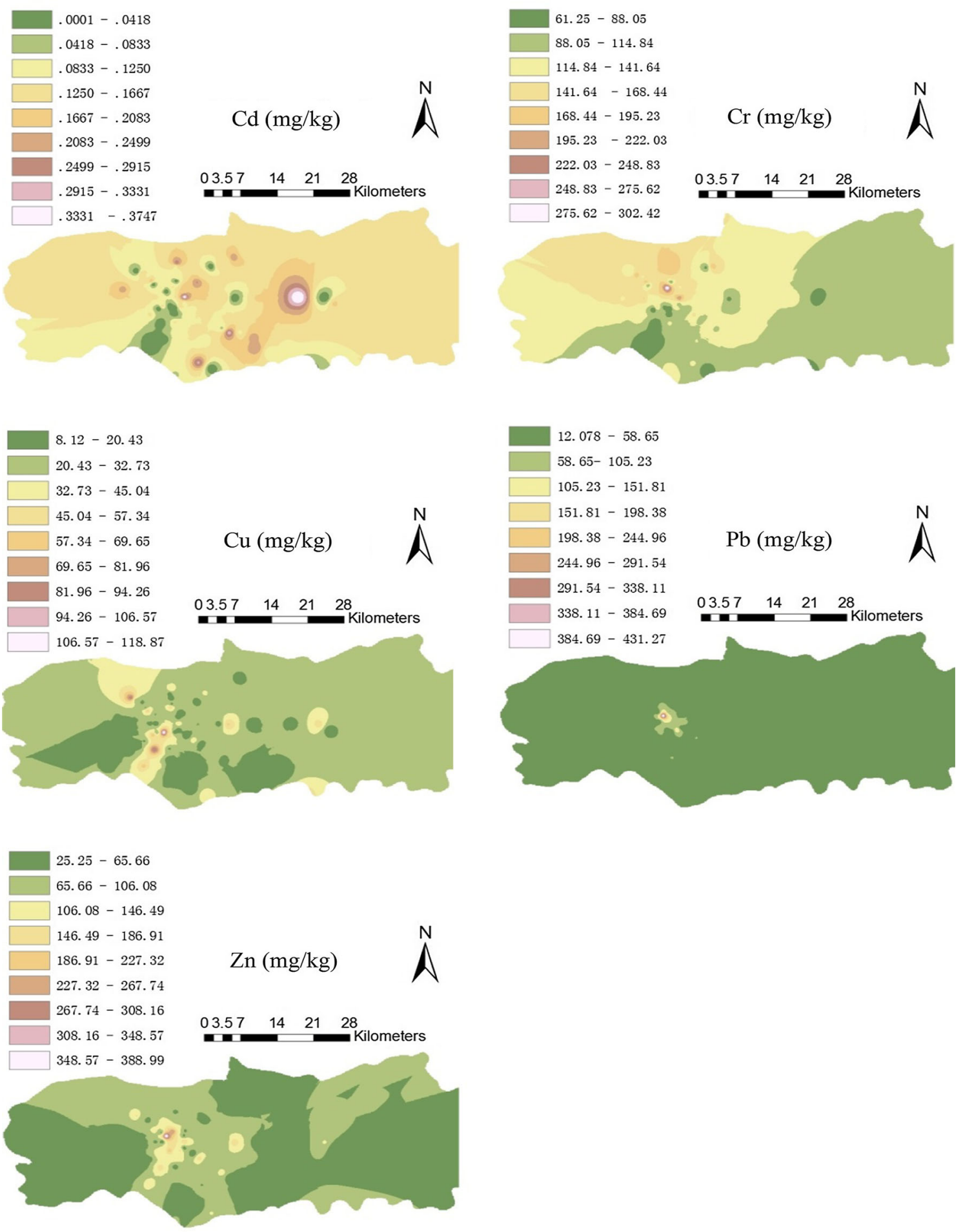

Fig. 5 Spatial distribution of $\mathrm{Cd}, \mathrm{Cr}, \mathrm{Cu}, \mathrm{Pb}$, and $\mathrm{Zn}$ in TA. In this figure, as legend shows, color is used to indicate different heavy metal concentrations. From dark green to white, the values change from the lowest to the highest concentrations (Color figure online)

with high potential ecological risk $(\mathrm{RI}>300)$. The same was true of the former site of the Mengyuan Dressing Plant, which was still heavily polluted with $\mathrm{Pb}$ and $\mathrm{Cd}$ but was slated to be redeveloped into a large commercial centre. Therefore, the soil quality of these brownfield sites remains poor, and much work is needed for further clean up and effectively managing the environmental risk of redevelopment. 


\section{Limitations of the Study}

This study aimed to provide a guide for planners concerned with the redevelopment of brownfield sites similar to those investigated here. Although the analytical results presented here were specific to the Bayan Obo mining and tailing dam areas, the policy suggestions could be transferable to similar sites. However, there were some details that may not transfer directly. First, pollution levels: the brownfield sites in the present study were found to be seriously polluted with HMs, but the pollution levels of other sites might not be the same. Second, evaluation timing: the timing of the evaluation affects the policy measuresideally, the evaluation should be carried out before any redevelopment takes place. In the present study, the redevelopment of most of the brownfield sites had not already taken place when the evaluation was carried out. Third, pollution depth: the contamination depth plays a decisive role in designing the remediation technology plan, that is, the evaluation depth of soil should be carried out according to the contamination depth. The present study only investigated the topsoil $(0-20 \mathrm{~cm}$ depth). Lastly, sampling intensity: the intensity of sampling is important, and it is critical for future studies to gain a visual image of the degree of pollution and the location of hot-spots. Because some sites in this study were under construction and unsafe to enter, the location of samples was restricted.

\section{Conclusions and Implications}

In this study, as the largest REE mineral deposit, the Bayan Obo mine with its large area of brownfields to be redeveloped has been used here as a case study to map and inventory HM pollution in mining brownfield sites in China.

The results of EF analysis indicated that the soils in the studied area were highly enriched with $\mathrm{HMs}(\mathrm{Cr}, \mathrm{Cd}, \mathrm{Pb}$, $\mathrm{Cu}$, and $\mathrm{Zn}$ ), compared to the corresponding background values. The $E_{\mathrm{r}}^{i}$ s showed that $\mathrm{Cd}$ pollution was the most prominent contaminant in the soil of the studied brownfield sites. The results of RI suggested that the soils in the MA and TA were widely polluted by multiple HMs with high ecological risks, resulting from long-term mining industrial activities. In addition, the most concentrated single contaminant may not be the most important area for remediation or policy intervention from a human or environmental health perspective. Soil pollution distribution maps of $\mathrm{Cr}$, $\mathrm{Cd}, \mathrm{Pb}, \mathrm{Cu}$, and $\mathrm{Zn}$ illustrated that many of the hot-spot areas were found in the locations of mining industrial sites. The results of combined statistical analyses and the distribution patterns of the HMs suggested that these ore mining and processing activities represented the primary pollutant sources for the Bayan Obo MA and TA. The analyses further indicated that the soil pollution in the MA and TA was serious and might pose ecological risks to the environment as well as health risks to local residents.

As a representative of traditional industrial cities, the Baotou municipal government launched a general investigation of soil pollution in Baotou city in 2007 and promulgated the Management Approach for Remediation of Contaminated Soil and Management Approach for Redevelopment of Contaminated Soil. However, the results of these approaches remain unknown because the related documents are not public. This investigation of the Banyan Obo brownfield sites indicated that a systemic approach was necessary to effectively manage contaminated soil in a sustainable way. Combined with the results of this study, such an approach should include the following two elements.

First, the national soil environmental quality standards should be revised with the least delay possible. While assessing the soil quality of the studied area, we found that although the average concentrations of HMs in both MA and TA were higher than their corresponding local background values and the results of the enrichment factor analysis (EF) and the potential ecological RI confirmed the existence of serious HM pollution, the average concentrations of HMs were extremely low compared with the Class II criteria of the National Environmental Quality Standards for Soil in China (GB 15618-1995). The standards' maximum acceptable concentrations were so high that if the assessment of soil quality is based on the National Environmental Quality Standards for Soil in China, soils with serious HM pollution would be identified as unpolluted. Therefore, there are many problems with the current standards, such as a "one size fits all" approach and high maximum acceptable concentrations, causing the standards to have little value for certain areas. The National Environmental Quality Standards for Soil in China have not been updated since they were introduced in 1995. Hence, there is an urgent need to revise the national soil environmental quality standards. The revised standards should replace the current "one size fits all" rules as well as the high maximum acceptable concentrations with specific criteria for particular land use types.

Second, the level of soil pollution should be a primary factor in development of the remediation plan and redevelopment plan as a prerequisite for effective management of contaminated soil. According to the results of our study, there were brownfield sites under soil HM pollution having been redeveloped into a park or a large commercial centre. In many Chinese cities, such as Hangzhou, Guangzhou, and Baotou, the redevelopment of brownfields takes place without remediation and without an investigation of soil pollution levels. Because exposure to pollutants in the soil 
has serious adverse effects on residents, brownfield remediation and redevelopment plans should be based on the degree of soil pollution. That is, a corresponding remediation plan should be made according to the degree of soil pollution. Municipal governments should also take the degree of soil pollution into consideration in urban planning.

In conclusion, this study demonstrates that redeveloping and managing brownfield sites are the urgent and long-term tasks for China.

Acknowledgments This work was sponsored by the Key Project of the Knowledge Innovation Program of IGSNRR (2012ZD002). We are grateful to Guiyue Chen and Jingwei Du for their sampling and analytical work at the early stages of the project. We also want to thank Drs. Ranjeet John, Chaoyang Wei, Lingqing Wang, Wenhui Kuang, and other anonymous reviewers for their helpful comments on the manuscript.

\section{References}

Acosta JA, Faz A, Martínez-Martínez S, Zornoza R, Carmona DM, Kabas S (2011) Multivariate statistical and GIS-based approach to evaluate heavy metals behavior in mine sites for future reclamation. J Geochem Explor 109:8-17. doi:10.1016/j.gexplo. 2011.01.004

Alloway B (2013) Sources of heavy metals and metalloids in soils. In: Alloway BJ (ed) Heavy metals in soils, vol 22. environmental pollution. Springer, Netherlands, pp 11-50. doi:10.1007/978-94007-4470-7_2

Arenas-Lago D, Andrade ML, Lago-Vila M, Rodríguez-Seijo A, Vega FA (2014) Sequential extraction of heavy metals in soils from a copper mine: distribution in geochemical fractions. Geoderma 230-231:108-118. doi:10.1016/j.geoderma.2014.04.011

ATSDR (2008) Public health statement of cadmium agency for toxic substances and diseases registry. US Department of Health and Human Services, Atlanda

Bes CM, Pardo T, Bernal MP, Clemente R (2014) Assessment of the environmental risks associated with two mine tailing soils from the La Unión-Cartagena (Spain) mining district. J Geochem Explor 147:98-106. doi:10.1016/j.gexplo.2014.05.020

Bradshaw A (1997) Restoration of mined lands: using natural processes. Ecol Eng 8:255-269. doi:10.1016/S0925-8574(97)00022-0

Candeias C, Melo R, Ávila PF, Ferreira da Silva E, Salgueiro AR, Teixeira JP (2014) Heavy metal pollution in mine-soil-plant system in S. Francisco de Assis : Panasqueira mine (Portugal). Appl Geochem 44:12-26. doi:10.1016/j.apgeochem.2013.07.009

Chang J, Zhang H, Ji M, Chen X-I (2009) Case study on the redevelopment of industrial wasteland in resource-exhausted mining area. Proc Earth Planetary Sc 1:1140-1146. doi:10.1016/ j.proeps.2009.09.175

Cheng F, Geertman S, Kuffer M, Zhan Q (2011) An integrative methodology to improve brownfield redevelopment planning in Chinese cities: a case study of Futian Shenzhen Computers. Environ Urban Syst 35:388-398. doi:10.1016/j.compenvurbsys. 2011.05.007

Cheng H, Li M, Zhao C, Li K, Peng M, Qin A, Cheng X (2014) Overview of trace metals in the urban soil of 31 metropolises in China. J Geochem Explor 139:31-52. doi:10.1016/j.gexplo. 2013.08.012
Christoforou CS, Salmon LG, Hannigan MP, Solomon PA, Cass GR (2000) Trends in fine particle concentration and chemical composition in southern California. J Air Waste Manag Assoc (1995) 50:43-53

Chrysochoou M, Brown K, Dahal G, Granda-Carvajal C, Segerson K, Garrick N, Bagtzoglou A (2012) A GIS and indexing scheme to screen brownfields for area-wide redevelopment planning. Landsc Urb Plan 105:187-198. doi:10.1016/j.landurbplan.2011. 12.010

CMYED (2007) China mining yearbook 2006. CMYED, Beijing

Drew LJ, Qingrun M, Weijun S (1990) The Bayan Obo iron-rareearth-niobium deposits, Inner Mongolia, China. Lithos 26:43-65. doi:10.1016/0024-4937(90)90040-8

Escarré J et al (2011) Heavy metal concentration survey in soils and plants of the Les Malines Mining District (Southern France): implications for soil restoration. Water Air Soil Pollut 216:485-504. doi:10.1007/s11270-010-0547-1

Esmaeili A, Moore F, Keshavarzi B, Jaafarzadeh N, Kermani M (2014) A geochemical survey of heavy metals in agricultural and background soils of the Isfahan industrial zone. Iran Catena 121:88-98. doi:10.1016/j.catena.2014.05.003

Facchinelli A, Sacchi E, Mallen L (2001) Multivariate statistical and GIS-based approach to identify heavy metal sources in soils. Environ Pollut 114:313-324. doi:10.1016/S0269-7491(00)00243-8

FAO (2014) World reference base for soil resources. Food and Agriculture Organization of the United Nations, Rome

Fryer M, Collins CD, Ferrier H, Colvile RN, Nieuwenhuijsen MJ (2006) Human exposure modelling for chemical risk assessment: a review of current approaches and research and policy implications. Environ Sci Policy 9:261-274. doi:10.1016/j. envsci.2005.11.011

Fu S, Wei CY (2012) Multivariate and spatial analysis of heavy metal sources and variations in a large old antimony mine, China. J Soils Sedim 13:106-116. doi:10.1007/s11368-012-0587-9

Guo W, Zhao R, Zhao W, Fu R, Guo J, Bi N, Zhang J (2013) Effects of arbuscular mycorrhizal fungi on maize (Zea mays L.) and sorghum (Sorghum bicolor L. Moench) grown in rare earth elements of mine tailings. Appl Soil Ecol 72:85-92. doi:10.1016/ j.apsoil.2013.06.001

Hakanson L (1980) An ecological risk index for aquatic pollution control: a sedimentological approach. Water Res 14:975-1001. doi:10.1016/0043-1354(80)90143-8

He ZL, Yang XE, Stoffella PJ (2005) Trace elements in agroecosystems and impacts on the environment. J Trace Elem Med Biol 19:125-140. doi:10.1016/j.jtemb.2005.02.010

Hough RL, Breward N, Young SD, Crout NM, Tye AM, Moir AM, Thornton I (2004) Assessing potential risk of heavy metal exposure from consumption of home-produced vegetables by urban populations. Environ Health Perspect 112:215-221

Huang L-M, Deng C-B, Huang N, Huang X-J (2013) Multivariate statistical approach to identify heavy metal sources in agricultural soil around an abandoned $\mathrm{Pb}-\mathrm{Zn}$ mine in Guangxi Zhuang Autonomous Region, China. Environ Earth Sci 68:1331-1348. doi:10.1007/s12665-012-1831-8

Jennings AA, Cox AN, Hise SJ, Petersen EJ (2002) Heavy metal contamination in the brownfield soils of cleveland. Soil Sedim Contam 11:719-750. doi:10.1080/20025891107069

Ji K et al (2013) Assessment of exposure to heavy metals and health risks among residents near abandoned metal mines in Goseong, Korea. Environ Pollut 178:322-328. doi:10.1016/j.envpol.2013. 03.031

Khalil A, Hanich L, Hakkou R, Lepage M (2014) GIS-based environmental database for assessing the mine pollution: A case study of an abandoned mine site in Morocco. J Geochem Explor 144(Part C):468-477. doi:10.1016/j.gexplo.2014.03.023 
Lam NS (2009) International encyclopedia of human geography. In: Kitchin R, Thrift N (eds) Spatial interpolation. Elsevier, Oxford, p 369. doi:10.1016/B978-008044910-4.00530-7

Li MS (2006) Ecological restoration of mineland with particular reference to the metalliferous mine wasteland in China: a review of research and practice. Sci Total Environ 357:38-53. doi:10. 1016/j.scitotenv.2005.05.003

Li X, Feng L (2012) Multivariate and geostatistical analyzes of metals in urban soil of Weinan industrial areas, Northwest of China. Atmos Environ 47:58-65. doi:10.1016/j.atmosenv.2011.11.041

Li J, Heap AD (2011) A review of comparative studies of spatial interpolation methods in environmental sciences: performance and impact factors. Ecol Inf 6:228-241. doi:10.1016/j.ecoinf. 2010.12.003

Li J, Hong M, Yin X, Liu J (2010) Effects of the accumulation of the rare earth elements on soil macrofauna community. J Rare Earths 28:957-964. doi:10.1016/S1002-0721(09)60233-7

Li J, Huabo D, Pixing S (2011) Heavy metal contamination of surface soil in electronic waste dismantling area: site investigation and source-apportionment analysis. Waste Manag Res ISWA 29:727-738. doi: $10.1177 / 0734242 \times 10397580$

Li Z, Ma Z, van der Kuijp TJ, Yuan Z, Huang L (2014) A review of soil heavy metal pollution from mines in China: pollution and health risk assessment. Sci Total Environ 468-469:843-853. doi:10.1016/j.scitotenv.2013.08.090

Li P, Lin C, Cheng H, Duan X, Lei K (2015) Contamination and health risks of soil heavy metals around a lead/zinc smelter in southwestern China. Ecotoxicol Environ Saf 113:391-399. doi:10.1016/j.ecoenv.2014.12.025

Liu G, Shu H (2003) Research progress of ecological restoration in mine spoils. Jiangxi For Sci Technol 02:21-25

Liu H, Probst A, Liao B (2005) Metal contamination of soils and crops affected by the Chenzhou lead/zinc mine spill (Hunan, China). Sci Total Environ 339:153-166. doi:10.1016/j.scitotenv. 2004.07.030

Liu Y-G, Zhang H-Z, Zeng G-M, Huang B-R, Li X (2006) Heavy metal accumulation in plants on $\mathrm{Mn}$ mine tailings. Pedosphere 16:131-136. doi:10.1016/S1002-0160(06)60035-0

Liu G, Tao L, Liu X, Hou J, Wang A, Li R (2013) Heavy metal speciation and pollution of agricultural soils along Jishui river in non-ferrous metal mine area in Jiangxi Province, China. J Geochem Explor 132:156-163. doi:10.1016/j.gexplo.2013.06.017

Manta DS, Angelone M, Bellanca A, Neri R, Sprovieri M (2002) Heavy metals in urban soils: a case study from the city of Palermo (Sicily), Italy. Sci Total Environ 300:229-243. doi:10. 1016/S0048-9697(02)00273-5

MEPPRC (2006) Report on the state of the environment in China. http://english.mep.gov.cn/standards_reports/soe/SOE2006/200711/ t20071106_112569.htm

Miao Z, Marrs R (2000) Ecological restoration and land reclamation in open-cast mines in Shanxi Province, China. J Environ Manag 59:205-215. doi:10.1006/jema.2000.0353

Mirzaei R, Ghorbani H, Hafezi Moghaddas N, Martín JAR (2014) Ecological risk of heavy metal hotspots in topsoils in the Province of Golestan, Iran. J Geochem Explor. doi:10.1016/j. gexplo.2014.06.011

Monterroso C, Rodríguez F, Chaves R, Diez J, Becerra-Castro C, Kidd PS, Macías F (2014) Heavy metal distribution in mine-soils and plants growing in a $\mathrm{Pb} / \mathrm{Zn}$-mining area in NW Spain. Appl Geochem 44:3-11. doi:10.1016/j.apgeochem.2013.09.001

Navarro MC, Pérez-Sirvent C, Martínez-Sánchez MJ, Vidal J, Tovar PJ, Bech J (2008) Abandoned mine sites as a source of contamination by heavy metals: a case study in a semi-arid zone. J Geochem Explor 96:183-193. doi:10.1016/j.gexplo. 2007.04.011
Nriagu JO, Pacyna JM (1988) Quantitative assessment of worldwide contamination of air, water and soils by trace metals. Nature 333:134-139. doi:10.1038/333134a0

NSPRC (1995) National Standards of the People's Republic of China (NSPRC). Standards for Soil Environmental Quality. GB156181995

Pardo T, Bernal MP, Clemente R (2014a) Efficiency of soil organic and inorganic amendments on the remediation of a contaminated mine soil: I-effects on trace elements and nutrients solubility and leaching risk. Chemosphere 107:121-128. doi:10.1016/j. chemosphere.2014.03.023

Pardo T, Clemente R, Alvarenga P, Bernal MP (2014b) Efficiency of soil organic and inorganic amendments on the remediation of a contaminated mine soil: II-biological and ecotoxicological evaluation. Chemosphere 107:101-108. doi:10.1016/j.chemo sphere.2014.03.017

Plum LM, Rink L, Haase H (2010) The essential toxin: impact of zinc on human health. Int J Environ Res Public Health 7:1342-1365. doi:10.3390/ijerph7041342

Sardinha ID, Craveiro D, Milheiras S (2013) A sustainability framework for redevelopment of rural brownfields: stakeholder participation at SÃO DOMINGOS mine, Portugal. J Clean Prod 57:200-208. doi:10.1016/j.jclepro.2013.05.042

S-h H (2014) Fractional distribution and risk assessment of heavy metal contaminated soil in vicinity of a lead/zinc mine. Trans Nonferrous Met Soc China 24:3324-3331. doi:10.1016/S10036326(14)63473-7

Shepard D (1968) A two-dimensional interpolation function for irregularly-spaced data. Paper presented at the proceedings of the 1968 23rd ACM national conference, Simon

Song L, Jian J, Tan D-J, Xie H-B, Luo Z-F, Gao B (2015) Estimate of heavy metals in soil and streams using combined geochemistry and field spectroscopy in Wan-sheng mining area, Chongqing, China. Int J Appl Earth Obs Geoinf 34:1-9. doi:10.1016/j.jag. 2014.06.013

Tang $\mathrm{Z}$ et al (2015) Contamination and risk of heavy metals in soils and sediments from a typical plastic waste recycling area in North China. Ecotoxicol Environ Saf 122:343-351. doi:10.1016/ j.ecoenv.2015.08.006

Vega FA, Covelo EF, Andrade ML (2006) Competitive sorption and desorption of heavy metals in mine soils: influence of mine soil characteristics. J Colloid Interface Sci 298:582-592. doi:10. 1016/j.jcis.2006.01.012

Wahsha M, Bini C, Argese E, Minello F, Fontana S, Wahsheh H (2012) Heavy metals accumulation in willows growing on Spolic Technosols from the abandoned Imperina Valley mine in Italy. J Geochem Explor 123:19-24. doi:10.1016/j.gexplo.2012.07.004

Wei C, Wang C, Yang L (2009) Characterizing spatial distribution and sources of heavy metals in the soils from mining-smelting activities in Shuikoushan, Hunan Province, China. J Environ Sci 21:1230-1236. doi:10.1016/S1001-0742(08)62409-2

Wong MH (2003) Ecological restoration of mine degraded soils, with emphasis on metal contaminated soils. Chemosphere 50:775-780. doi:10.1016/S0045-6535(02)00232-1

Wu C (2008) Bayan Obo controversy: carbonatites versus iron oxide$\mathrm{Cu}-\mathrm{Au}-(\mathrm{REE}-\mathrm{U})$. Resour Geol 58:348-354. doi:10.1111/j.17513928.2008.00069.x

Xie Y, Chen T-B, Lei M, Yang J, Guo Q-J, Song B, Zhou X-Y (2011) Spatial distribution of soil heavy metal pollution estimated by different interpolation methods: accuracy and uncertainty analysis. Chemosphere 82:468-476. doi:10.1016/j.chemosphere. 2010.09 .053

$\mathrm{Xu} \mathrm{S}$, Tao S (2004) Coregionalization analysis of heavy metals in the surface soil of Inner Mongolia. Sci Total Environ 320:73-87. doi:10.1016/s0048-9697(03)00450-9 
Yan W et al (2015) The spatial distribution pattern of heavy metals and risk assessment of moso bamboo forest soil around lead-zinc mine in Southeastern China. Soil Tillage Res 153:120-130. doi:10.1016/j.still.2015.05.013

Yang Z, Lu W, Long Y, Bao X, Yang Q (2011) Assessment of heavy metals contamination in urban topsoil from Changchun City, China. J Geochem Explor 108:27-38. doi:10.1016/j.gexplo. 2010.09.006

Yuan Z, Ge B, Chenyu W, Zhongqin Z, Xianjiang Y (1992) Geological features and genesis of the Bayan Obo REE ore deposit, Inner Mongolia, China. Appl Geochem 7:429-442. doi:10.1016/0883-2927(92)90004-M

Zhang S, Lin Y, Hua X, Yigang X, Tian M, Xiliu J (2007) The facing problems and countermeasures of chinese contaminated cite management. Environ Sci Manag 6:5-7

Zhang X, Yang L, Li Y, Li H, Wang W, Ye B (2012) Impacts of lead/ zinc mining and smelting on the environment and human health in China. Environ Monit Assess 184:2261-2273. doi:10.1007/ s10661-011-2115-6

Zhao H, Xia B, Fan C, Zhao P, Shen S (2012) Human health risk from soil heavy metal contamination under different land uses near Dabaoshan Mine, Southern China. Sci Total Environ 417-418:45-54. doi:10.1016/j.scitotenv.2011.12.047

Zhuang P, McBride MB, Xia H, Li N, Li Z (2009) Health risk from heavy metals via consumption of food crops in the vicinity of Dabaoshan mine, South China. Sci Total Environ 407:1551-1561. doi:10.1016/j.scitotenv.2008.10.061

Zhuang P, Li Z-A, Zou B, Xia H-P, Wang G (2013) Heavy metal contamination in soil and Soybean near the Dabaoshan Mine, South China. Pedosphere 23:298-304. doi:10.1016/S10020160(13)60019-3 